\title{
Evaluation of Socio-Economic Factors Related to Helicobacter Pylori Infection in Duhok City
}

Mohammed Haydar Musa*

Jihan Noori Hussein**

\begin{abstract}
Background and aim: Helicobacter pylori $(\mathrm{Hp})$ are found in half the population of the world. Its prevalence is highly variable in relation to geography, ethnicity, age, and socioeconomic factors-high in developing countries and lower in the developed world. This study aims to estimate the prevalence of Helicobacter pylori among patients in Duhok, and to identify factors associated with of Helicobacter pylori among patients in Duhok.
\end{abstract}

Materials and method: A cross-sectional study was carried out throughout the present study among patients who attending to Duhok gastroenterology and hepatology center. The study included (80) samples of nurses for the period from $10^{\text {th }}$ January to $5^{\text {th }}$ December 2015 .The study revealed that there were significant statistical results related to income, residency, water source and blood group to be considered as a risk factor of $\mathrm{H}$. pylori infection.

Results: The study revealed that there were no significant statistical results related to age to be considered as a risk factor at $(\mathrm{p}<0.05)$. Among the 80 patients who completed data, the highest positive result was found in the age group of 20-30 years (68.18.7\%) while the highest negative result was found in the age group of $50-60 \mathrm{yr}(42.86 \%)$.

Conclusion: There were significant difference between $H$. pylori infection and some variables like (age, sex, married status, level of education and smoking and coffee consumption and years of experience).

Keywords: $H$. pylori - prevalence - risk factors, socioeconomic status.

\section{INTRODUCTION}

Helicobacter pylori (Hp) is a spiral shaped micro-aerophilic Gram negative bacterium that colonizes the gastric mucosa and induces a strong inflammatory response with release of various bacterial and host dependent cytotoxic substances (Nedrud and Czinn, 1997). Helicobacter pylori, formerly known as Campylobacter pylori, colonizes and grows in human gastric epithelial tissue and mucus (Labigne and de Reuse, 1996). Its presence is associated with gastritis; substantial evidence indicates that it causes peptic ulcers, duodenal ulcers, and chronic gastritis and that it is also involved in the development of gastric cancer (McColl, 1997; Riegg et. al., 1995).This gram negative bacterium infects human gastric mucosa causing long term colonization and inflames mation (Brown et. al., 2002). H. pylori, colonizes the human stomach, can cause gastritis, is strongly associated with gastric and duodenal ulceration (DU) and has been implicated in the causation of gastric carcinoma and mucosa-associated lymphoid tissue (MALT) lymphomas (Chun et. al., 2000). Moreover, Helicobacter pylori is well recognized as a class I carcinogen because chronic inflammation and atrophy can further lead to malignant transformation (Fox and Wang, 2007).

Helicobacter pylori ( $\mathrm{Hp}$ ) are found in half the population of the world (Goodwin et. al., 1997). Its prevalence is highly variable in relation to geography, ethnicity, age, and socioeconomic factors-high in developing countries and lower in the developed world. In general, however, there has been a decreasing trend in the prevalence of $\mathrm{Hp}$ in many parts of the world in recent years (Hunt et. al., 2010). Epidemiological studies have shown that a weakly positive correlation exists between chronic gastric infection with $H$. pylori and coronary heart disease (Danesh et. al., 1997).

Approximately $20 \%$ of persons infected with $H$. pyloridevelop related gastroduodenal disorders during their lifetime (Lacy and Semore, 2001). Documented risk factors include low socioeconomic status, overcrowding, poor sanitation or hygiene, and living in a developing country (Brown, 2000). The general purpose of this study is to identification and determination the socio-economic factors related to Helicobacter pylori infection who attending Duhok gastroenterology and hepatology center. The specific objectives of this study are to estimate the prevalence of Helicobacter pylori among patients in Duhok, and to identify factors associated with of Helicobacter pylori among patients in Duhok.

\section{MATERIALS AND METHOD}

A cross-sectional study was carried out

* Lecturer / Technical Institute / Duhok.

** Assistant Lecturer/ Technical Institute/ Duhok. 
throughout the present study from the period $10^{\text {th }}$ December to $5^{\text {th }}$ January 2015 in order to achieve the objectives of the study. The study was carried out among patients who attending to Duhok gastroenterology and hepatology center. Prior to the data collection, a formal administrative approval was obtained from Duhok Directorate of the health / Duhok gastroenterology and hepatology center to conduct the present study. The study participants were dyspeptic patients from outpatients department with symptoms such as upper abdominal pain or discomfort bloating, nausea, vomiting epigastric pain for at least 3 months. The total study population was 80 Patients randomly selected eligible patients were subjected for blood sample collection. All patients were interviewed. Verbal consent was obtained from all patients. Study tool "questionnaire" was validated by a number of referees and based on literature review when developed by the researcher to ensure culture and language appropriateness. After the arrangement of information obtained from referees, the tools of the study consisted of two parts: the first part of the questionnaire contained questions regarding the demographic data (age, gender, residency, blood group and family income), the second part referred to selected features relating to the patients' lifestyle such as living conditions, smoking, coffee consumption, source of water and living with someone who has an $\mathrm{H}$. pylori infection. About $2 \mathrm{ml}$ of venous blood was collected from each volunteer patient by venipuncture for $H$. pylori IgM serum determination. Artron rapid Helicobacter pylori (H.pylori, or HP, United Kingdom) anti body (immunochromatographic) assay used for the qualitative detection of H.pylori antibody in serum samples. This test coated on the surface of micro well. Three full drops of patient's serum was added to the well without air bubbles then read of color absorbance and result interpretation was done according to the manufacturer recommendations. Percentages were used to calculate the description of the sample. Chi-square test to determine the prevalence of $H$. pylori infection in the participants, and the difference in the prevalence across gender and stages. The differences between means were considered significant when $\mathrm{P} \leq 0.05$.

\section{RESULTS}

\section{Figure (1): Level of education}

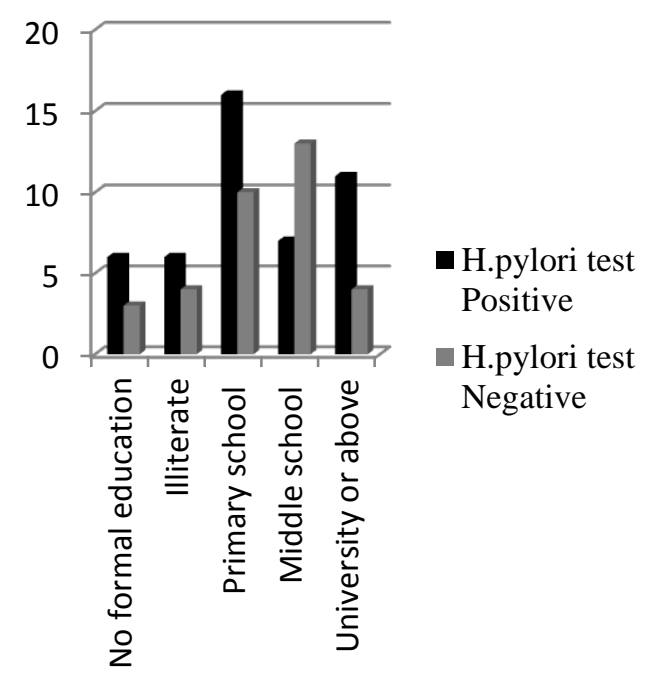

Table (1): Gender and H. pylori

\begin{tabular}{|c|c|c|c|c||}
\hline \multirow{2}{*}{ Gender } & \multicolumn{2}{|c|}{ H.pylori test } & \multirow{2}{*}{ total } & \multirow{2}{*}{ P. } \\
\cline { 2 - 3 } & Positive & Negative & & \\
\hline \multirow{2}{*}{ Male } & 24 & 14 & 38 & \\
& $(63.16 \%)$ & $(36.84 \%)$ & $(47.5 \%)$ & \multirow{2}{*}{0.33} \\
\hline \multirow{2}{*}{ Female } & 22 & 20 & 42 & \\
& $(52.38 \%)$ & $(47.62 \%)$ & $(52.5 \%)$ & \multirow{2}{*}{0.30} \\
\hline \multirow{2}{*}{ Total } & 46 & $\begin{array}{c}34 \\
(57.5 \%)\end{array}$ & $\begin{array}{c}82.5 \%) \\
(100 \%)\end{array}$ & \\
\hline
\end{tabular}

Table (2): H. pylori infection in relation to

\begin{tabular}{|c|c|c|c|c|}
\hline \multirow{2}{*}{ Age } & \multicolumn{2}{|c|}{ H.pylori test } & \multirow{2}{*}{ total } & \multirow{2}{*}{ P. } \\
\hline & Positive & Negative & & \\
\hline $20-30$ & $\begin{array}{c}15 \\
(68.18 \%)\end{array}$ & $\begin{array}{c}7 \\
(31.82 \%)\end{array}$ & $22(27.5 \%)$ & 0.275 \\
\hline $31-40$ & $\begin{array}{c}13 \\
(50 \%) \\
\end{array}$ & $\begin{array}{c}13 \\
(50 \%) \\
\end{array}$ & $\begin{array}{c}26 \\
(32.5 \%) \\
\end{array}$ & 0.325 \\
\hline $41-50$ & $\begin{array}{c}10 \\
(55.56 \%)\end{array}$ & $8(44.44 \%)$ & $\begin{array}{c}18 \\
(22.5 \%) \\
\end{array}$ & 0.225 \\
\hline $51-60$ & $\begin{array}{c}8 \\
(57.14 \%)\end{array}$ & $\begin{array}{c}6 \\
(42.86 \%)\end{array}$ & $\begin{array}{c}14 \\
(17.5 \%)\end{array}$ & 0.175 \\
\hline Total & $\begin{array}{c}46 \\
(57.5 \%)\end{array}$ & $\begin{array}{c}34 \\
(42.5 \%)\end{array}$ & $\begin{array}{c}80 \\
(100 \%)\end{array}$ & \\
\hline
\end{tabular}

Table (3): H. pylori infection rates in relation to the residency

\begin{tabular}{||c|c|c|c|c||}
\hline \multirow{2}{*}{ Residency } & \multicolumn{2}{|c|}{ H.pylori test } & \multirow{2}{*}{ total } & \multirow{2}{*}{ P. } \\
\cline { 2 - 3 } & Positive & Negative & & \\
\hline \multirow{2}{*}{ Urban } & $\begin{array}{c}15 \\
(44.12 \%)\end{array}$ & $\begin{array}{c}19 \\
(55.88 \%)\end{array}$ & $\begin{array}{c}34 \\
(57.5 \%)\end{array}$ & \\
\hline \multirow{2}{*}{ Rural } & $\begin{array}{c}31 \\
(67.39 \%)\end{array}$ & $\begin{array}{c}15 \\
(32.61 \%)\end{array}$ & $\begin{array}{c}46 \\
(42.5 \%)\end{array}$ & \multirow{2}{*}{0.04} \\
\hline \multirow{2}{*}{ Total } & 46 & 34 & 80 & \\
& $(57.5 \%)$ & $(42.5 \%)$ & $(100 \%)$ & \\
\hline
\end{tabular}


Figure (2): H. pylori infection rates in relation to occupation

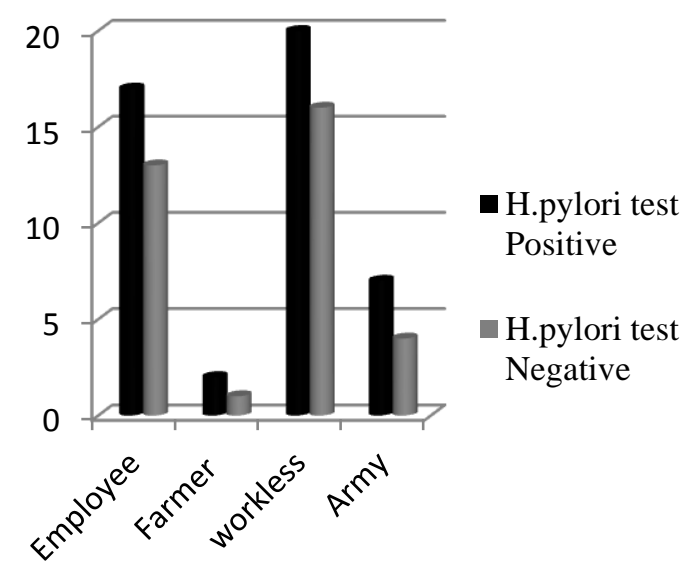

Table (6): Material state and $H$. pylori

\begin{tabular}{|l|c|c|c|c||}
\hline \multirow{2}{*}{$\begin{array}{l}\text { Marital } \\
\text { statutes }\end{array}$} & \multicolumn{2}{|c|}{ H. pylori test } & \multirow{2}{*}{ Total } & \multirow{2}{*}{ P. } \\
\cline { 2 - 4 } Positive & Negative & & \\
\hline Married & $\begin{array}{c}33 \\
(55 \%)\end{array}$ & $\begin{array}{c}27 \\
(45 \%)\end{array}$ & $\begin{array}{c}60 \\
(75 \%)\end{array}$ & \\
\cline { 1 - 4 } Single & $\begin{array}{c}13 \\
(65 \%)\end{array}$ & $\begin{array}{c}7 \\
(35 \%)\end{array}$ & $\begin{array}{c}20 \\
(25 \%)\end{array}$ & \multirow{2}{*}{0.433} \\
\hline Divorced & $0(0 \%)$ & $0(0 \%)$ & $0(0 \%)$ & \\
\hline Total & $\begin{array}{c}46 \\
(57.5 \%)\end{array}$ & $\begin{array}{c}34 \\
(42.5 \%)\end{array}$ & $\begin{array}{c}80 \\
(100 \%)\end{array}$ & \\
\hline
\end{tabular}

Figure (3) :Coffee consumption

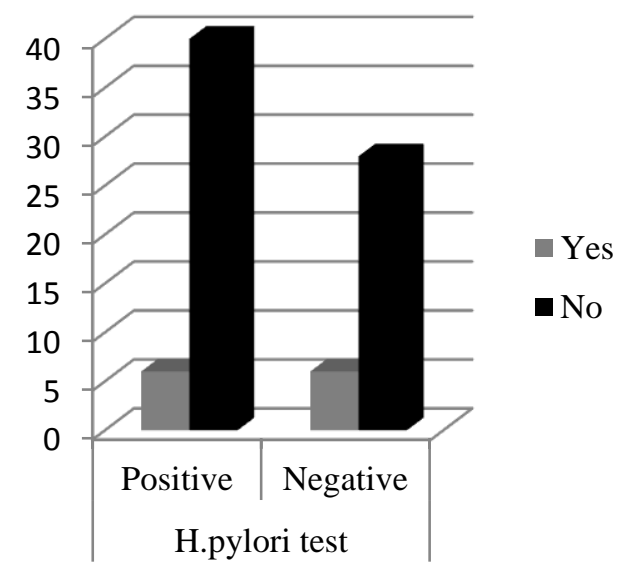

Table (7): $\mathrm{H}$. pylori infection in relation to water source

\begin{tabular}{|c|c|c|c|c||}
\hline \multirow{2}{*}{ Water source } & \multicolumn{2}{|c|}{ H .pylori test } & \multirow{2}{*}{ Total } & \multirow{2}{*}{$\mathrm{P}$} \\
\cline { 2 - 4 } & Positive & Negative & & \\
\hline \multirow{2}{*}{ Municipality } & $\begin{array}{c}33 \\
(50.77 \%)\end{array}$ & $\begin{array}{c}32 \\
(49.23 \%)\end{array}$ & $\begin{array}{c}65 \\
(81.25 \%)\end{array}$ & \\
\hline Wells & $\begin{array}{c}6 \\
(66.67 \%)\end{array}$ & $\begin{array}{c}3 \\
(33.33 \%)\end{array}$ & $\begin{array}{c}9 \\
(11.25 \%)\end{array}$ & \multirow{2}{*}{0.053} \\
\hline Filtered & 6 & 0 & 6 \\
water & $(100 \%)$ & $(0 \%)$ & $(7.5 \%)$ & \\
\hline Total & $\begin{array}{c}46 \\
(57.5 \%)\end{array}$ & $\begin{array}{c}34 \\
(42.5 \%)\end{array}$ & $\begin{array}{c}80 \\
(100 \%)\end{array}$ & \\
\hline
\end{tabular}

Table (8): H. pylori infection in relation to blood group

\begin{tabular}{||c|c|c|c|c||}
\hline \hline \multirow{2}{*}{$\begin{array}{c}\text { Blood } \\
\text { group }\end{array}$} & \multicolumn{2}{|c|}{ H. pylori test } & \multirow{2}{*}{ Total } & \multirow{2}{*}{ P. } \\
\cline { 1 - 3 } & Positive & Negative & & \\
\hline A & $\begin{array}{c}2 \\
(20 \%)\end{array}$ & $\begin{array}{c}8 \\
(80 \%)\end{array}$ & $\begin{array}{c}10 \\
(12.5 \%)\end{array}$ & \\
\hline B & $\begin{array}{c}6 \\
(54.55 \%)\end{array}$ & $\begin{array}{c}5 \\
(45.45 \%)\end{array}$ & $\begin{array}{c}11 \\
(13.75 \%)\end{array}$ & \\
\hline AB & $\begin{array}{c}2 \\
(40 \%)\end{array}$ & $\begin{array}{c}3 \\
(60 \%)\end{array}$ & $\begin{array}{c}5 \\
(6.25 \%)\end{array}$ & \multirow{2}{*}{0.041} \\
\hline O & $\begin{array}{c}36 \\
(66.67 \%)\end{array}$ & $\begin{array}{c}18 \\
(33.33 \%)\end{array}$ & $\begin{array}{c}54 \\
(67.5 \%)\end{array}$ & \\
\hline Total & $\begin{array}{c}46 \\
(57.5 \%)\end{array}$ & $\begin{array}{c}34 \\
(42.5 \%)\end{array}$ & $80(100 \%)$ & \\
\hline
\end{tabular}

DISCUSSION

A total of 80 volunteers participated in this study. Our study showed that $H$. pylori was positive in $46(57.5 \%)$ patients, $42(52.5 \%)$ of them were female and $38(47.5 \%)$ were male (Table 1).

H. pylori infection was higher $(32.5 \%)$ among patients aged (31-40) years than those patients aged (20-30) year (27.5\%), those aged (41- 50) year $(22.5 \%)$ and those aged (51-60) year $(17.5 \%)$ (Table 2). 46 patients living in rural and 34 from urban, and there are significant difference found between them (Table 3).

Figure (1) shows that there are no significant differences at $(p<0.05)$ among the volunteers patients with regard to the level of education using chi-square-test.

Table (4) demonstrate that the high percentages of patients $(75 \%)$ never smoking, while the low percentages of patients $(6.25 \%)$ current smoking, and there are no significant difference found between them using chi-squaretest.

Table (5) shows that the high percentage of the participants patients $42(52.5 \%)$ were from low income social class and there are significant difference found between them $\left(\mathrm{X}^{2}=\right.$ 0.052) .

Table (6) describes the marital statutes of patients in the study sample. As evident from the table, the highest percentages of patients were married $60(75 \%)$, and there are no significant difference found between them $\left(X^{2}=0.433\right)$.

With regard to water source, it appears from table (7) the source of drinking water had a strong effect on the prevalence of $H$. pylori infection. The prevalence of infection among Municipality water drinkers was $65(81.25 \%)$ compared with $6(7.5 \%)$ among those who 
drank Filtered water, and there are significant difference found between them $\left(X^{2}=0.053\right)$.

Table (8) shows that there are significant differences at $(\mathrm{p}<0.05)$ among patients with regard to the blood group $(\mathrm{X} 2=0.074)$.

Figure (2) indicates that there are no significant differences at $(\mathrm{p}<0.05)$ among patients with regard to the occupation $\left(\mathrm{X}^{2}=\right.$ 0.952).

It appears from figure (3) that that there are no significant differences at $(\mathrm{p}<0.05)$ among patients with regard to the coffee consumption $\left(\mathrm{X}^{2}=0.569\right)$. Helicobacter pylori are recognized as the main etiological agent of gastritis in human beings and as an essential factor in the pathogenesis of peptic ulcer. (Mégraud and Lamouliatte, 1992).

In order to know whether there are effects of the socio-demographic factors of the patients on the positive result of $\mathrm{H}$. pylori, the researchers categorized the sample of the study to many groups according to certain variables. As shown in table (1) there is no significant difference in the overall prevalence of $H$. pylori infection between males and females. This result is in agreement with (Rodrigues $\mathrm{M}$ ) which indicated that there are no significant gender differences $(\mathrm{p}<0.05)$ (Rodrigues et. al., 2005). This finding is also supported by those reported from south-eastern and central south Brazil, and from Africa and India (Graham et. al., 1991). As has also been found in other studies made in developing countries, there were no gender differences in the risk of acquisition of infection (Sathar et. al., 1997).

The study revealed that there were no significant statistical results related to age to be considered as a risk factor at $(\mathrm{p}<0.05)$. Among the 80 patients who completed data, the highest positive result was found in the age group of 2030 years $(68.18 .7 \%)$ while the highest negative result was found in the age group of $50-60 \mathrm{yr}$ $(42.86 \%)$ (table 2). Studies conducted in Bhutan by Dorji et. al. (2013) and in China by Zhang et. al. (2013) documented identical prevalence with no statistically significance different among age group.

Figure (1) indicates that there are no significant differences among patients with regard to the level of education at $(\mathrm{p}<0.05)$. The highest positive results were in primary school level (61.54\%) and the lowest positive result was in illiterate level (60\%). This finding is in agreement with a study conducted in Brazil, the study showed that there were no significant differences in the prevalence of $\mathrm{H}$. pylori infection, when patients were classified by educational level (Rodrigues et. al., 2005). Another study in south of Brazil conducted by Ina and Jose (2005) showed different results. In crude analyses, prevalence was associated with increasing lower education level. With regard to residency, it was revealed that there were significant differences among samples at $(\mathrm{p}<0.05)$. This result is an agreement with the results of Zhannat et. al. (2002). Which indicates that there were no significant differences among patients with regard to residency.

Also this result is an agreement with the results of Tajeldin et. al. (2014), which show in his study highlighted the high prevalence of $\mathrm{H}$. pylori infection and its association with rural residency (table 3). Smoking is considered as a risk factor for many diseases and is implicated by several studies in the literature as a risk factor for $H$. pylori infection. However, the results of this study showed no statistical differences between smokers and non-smokers with regard to H. pylori infection (table 4). This result is an agreement with Murray et. al. (1997), which indicate that there were no significant differences association between smoking and $\mathrm{H}$. pylori prevalence, and result is disagree with result of El-Barrawy (1997), which demonstrated that $\mathrm{H}$. pylori infection prevailed mostly $(70 \%)$ in smokers. According to odds ratio, the risk of infection was 5.3 times higher for smokers than nonsmokers.

There are reasons why smoking might have little effect on, or even increase, the hostility of the gastric environment to $H$. pylori. The acid gastric $\mathrm{pH}$ prevents most organisms from thriving or even surviving in the stomach. H.pylori, however, has an electropositive internal milieu; twice the number of basic amino acids, arginine and lysine, as Haemophilus influenzae and Escherichia coli; and powerful urease activity, with the ability to produce both ammonia and factors that inhibit parietal cell acid production (Tomb et. al., 1997). The study revealed that there were significant statistical results related to income to be considered as a risk factor at $(\mathrm{p}<0.05)$. Table $(5)$. This result is in agreement with the results of Blaser (2004), which indicates that there were significant differences in the prevalence of $H$. pylori infection with regard to income level.

Figure (2) Show that there were no significant differences among patients with regard to the occupation at $(\mathrm{p}<0.05)$. This result is an disagreement with Matysiak-Budnik (1997), which shows an association between 
occupational exposure and an increased risk of infection.

The result of the study shows marital status is not a risk factor as shown in table (6), although a slightly higher percentage of $\mathrm{H}$. pylori infection was observed among married than single subjects. However, the increase was not statistically significant $(\mathrm{X} 2=0.433)$. This result is an disagreement with the results of Bakka (2002), which showed a higher prevalence of $\mathrm{H}$. pylori in married subjects (84\%) in comparison to single subjects (68\%).

The hypothesis of water being a route of transmission of H. pylori (Engstrand, 2001). Our study shows that there were statistically significant relationship between source of water and prevalence of $\mathrm{H}$. pylori infection $(\mathrm{X} 2=$ 0.053) (table 7), and this result is supported by Klein (1991), which indicated the water supply was an important source of $\mathrm{H}$. pylori infection in families with high or low social economic levels. With regard to coffee consumption, it was revealed that there were no significant differences among patients at $(\mathrm{p}<0.05)$ (Figure 3 ).Our result is an incompatible with result of Gamal (2013), which found in his study that coffee consumption is considered as a risk factor for $\mathrm{H}$. pylori infection. The results of this study showed that there was a significant association between $\mathrm{ABO}$ blood groups and $H$. pylori infection $(\mathrm{X} 2=0.041)$, in which type $\mathrm{O}$ has a greater tendency towards infection $(64.29 \%)$. These results are reinforced by data obtained from other researchers showing the greater susceptibility of blood group $\mathrm{O}$ to $H$. pylori infection (Kanbay et. al., 2005; Mattos et. al., 2002).

\section{CONCLUSION}

According to the results of the data analysis, the following conclusions have been inferred in our study we found that the incidence of $\mathrm{H}$. pylori positivity was $57.5 \%$ and there was statistically significant difference between $\mathrm{H}$. pylori infection and some variables like (residency, income level, water source, and blood group). There were significant difference between $\mathrm{H}$. pylori infection and some variables like (age, sex, married status, level of education and smoking and coffee consumption and years of experience).

\section{REFERENCES}

Nedrud, JG.; Czinn, SJ. (1997). Helicobacter pylori. Curr Opin Gastroenterol. 13. P.p.71-78.
Labigne, A.; and de Reuse H. (1996). Determinants of Helicobacter pylori pathogenicity. Infectious Agents and Diseases. 5. P.p.191-202.

McColl, KEL. (1997). Helicobacter pylori: clinical aspects. Journal of Infection. 34. P.p.7-13.

Riegg, SJ.; Dunn, BE.; Blaser, MJ. (1995). Microbiology and pathogenesis of Helicobacter pylori. In: Blaser, MJ. et. al. Infections of the gastrointestinal tract. New York, Raven Press. P.p.535550.

Brown, L M.; Thomas, T L.; et. al. (2002). Helicobacter pylori infection in rural China. International Journal of Epidemiology. 31(3). P.p. 638-645.

Chun, D.; Shun, N.; Shi, H.; Jia, Y. (2000). Seroepidemiology of Helicobacter pylori infection among asymptomatic Chinese children. World J. Gastroenterol. 6(5). P.p.759-761.

Fox, J. G.; and Wang, T. C. (2007). "Inflammation, atrophy, and gastric cancer". Journal of Clinical Investigation. 117(1). P.p. 60-69.

Goodwin, CS.; Mendall, MM.; Northfield, TC. (1997). Helicobacter pylori infection. Lancet. 349. P.p.265-269.

Hunt. et. al. (August, 2010). Helicobacter pylori in developing countries, World Gastroenterology Organisation Global Guidelines. P. p.3.

Danesh, J.; Collins, R.; Peto, R. (1997). Chronic infections and coronary heart disease: is there a link?. Lancet. 350 ( 9075). P.p.430-436.

Lacy, B.; Semore, J. (2001). Helicobacter pylori: ulcers and more: the beginning of an era. J Nutr. 131(27). P.p.89-93.

Brown, L. (2000). Helicobacter pylori: epidemiology and routes of transmission. Epidemiol Rev. 22(2). P.p.83-97.

Mégraud, F.; Lamouliatte, H. (1992). Helicobacter pylori and duodenal ulcer. Dig Dis Sci. 37. P.p.769-772.

Rodrigues, M.; Queiroz, D.; Rodrigues, R.; Rocha, A.; Braga, Neto M.; et. al. (2005). Helicobacter pylori infection in adults from a poor urbancommunity in northeastern Brazil: demographic, lifestyle and environmental factors. Braz J Infect Dis. 9(5). P.p.405-410.

Graham, D.; Malaty, H.; Dolores, G.; et. al. (1991). Epidemiology of Helicobacter 
pylori in an Asymptomatic Population in the United States. Effect of Age, Race and Socioeconomic Status. Gastroenterol. 100(6). P.p.1495- 1501.

Sathar, M.; Gouws, E.; Simjeea, E.; Mayat, A. (1997). Seroepidemiological study of H. pylori infection in South African. Trans $R$ Soc Trop Med Hyg. 91(4). P.p.393395.

Dorji, D.; Dendup, T.; Malaty, HM.; et. al. (2013). Epidemiology of Helicobacter pylori in Bhutan: the role of environment and geographic location. Helicobacter.19. P.p. 69-73.

Zhang, B.; Hao, GY.; Gao, F.; et. al. (2013). Lack of association of common polymorphisms in MUC1 gene with Helicobacter pylori infection and noncardia gastric cancer risk in a Chinese population. Asian Pac J Cancer Prev. 14. P.p.7355-8.

Rodrigues, M.; Queiroz, D.; Rodrigues, R.; Rocha, A.; Braga Neto, M.; et. al. (2005). Helicobacter pylori infection in adults from a poor urban community in northeastern Brazil: demographic, lifestyle and environmental factors. Braz J Infect Dis. 9(5). P.p.405-410.

Ina, S.; Jose, B.; Ari, S.; Neiva, C.; Camila, S.; et. al. (2005). Prevalence of Helicobacter pylori infection and associated factors among adults in Southern Brazil: a population-based cross-sectional Study. BMC Public Health. 5(118). P.p.1-10.

Zhannat, z.; et. al. (2002). Helicobacter pylori infection in kazakhstan: effect of water source and household hygiene. Am. J. Trop. Med. Hyg. 67(2). P.p. 201-206.

Tajeldin Mohammedien Abdallah1; Hashim Balla Mohammed; Mamoon Hassan Mohammed. (2014). Asian Pacific Journal of Tropical Disease.. 4(2). P.p.115-119.

Murray, LJ.; et. al. (1997). Epidemiology of Helicobacter pylori infection among 4742 randomly selected subjects from Northern Irland. Int J Epidemiol. 26. P.p.880-887.
El-Barrawy, M.; Morad, M.; Gaber, M. (1997). Role of Helicobacter pylori in the genesis of gastric ulcerations among smokers and nonsmokers. East Medit. Health J. 3(2). P.p.316-321.

Tomb, J.; White, O.; Kerlavage, A.; Clayton, R.; Sutton, G.; et. al. (1997). The complete genome sequence of the gastric pathogen Helicobacter pylori. Nature. 388(6642). P.p.539-47.

Blaser, M.; Atherton, J. (2004). Helicobacter pylori persistence: Biology and disease. J Clin Invest. 113(3). P.p.321 333.

Matysiak-Budnik, T.; Megraud, F. (1997). Epidemiology of Helicobacter pylori infection with special reference to professional risk. J Physiol Pharmacol. 48(Suppl 4). P.p.3-17.

Bakka, A.; Salih, B. (2002). Prevalence of Helicobacter pylori infection in asymptomatic subjects in Libya. Diagn Microbiol Infect Dis. 43(4). P.p.265268.

Engstrand L. (2001). Helicobacter in water and waterborne routes of transmission. Symp Ser Soc Appl Microbiol. P.p.80S-4S.

Klein, P.D.; Graham, D.Y.; Gaillour, A.; et al. (1991). Water source as risk factor for Helicobacter pylori infection in Peruvian children. Lancet. 337. P.p.1503-6.

Gamal, A. A-Ameri; and Mawhoob, Noman Alkadasi. (2013). The prevalence of Helicobacter pylori and risk factors infection associated in Taiz city, Yemen. International Journal of current Microbiology and Applied Sciences. 2 (8). P.P. 226-233.

Kanbay, M.; Gur, G.; Arslan, H.; Yilmaz, U.; and Boyacioglu, S. (2005). "The relationship of $\mathrm{ABO}$ blood group, age, gender, smoking and Helicobacter pylori infection'. Dig. Dis. Sci. 50 (7) P.p.1214-1217.

Mattos, L.C.; Cintra, J.R; Sanches, F.E.; Alves, R.C.; Ruiz, M.A.; and Moreira, H.W. (2002). "ABO, Lewis, secretor and nonsecretor phenotypes in patients infected or uninfected by the Helicobacter pylori bacillus". Sao. Paulo. Med. J. 120 (2). P.p.55-58. 